\title{
Influence of sonication on Warner-Bratzler shear force, colour and myoglobin of beef ( $m$. semimembranosus)
}

\author{
Joanna Stadnik • Zbigniew J. Dolatowski
}

Received: 9 May 2011/Revised: 15 July 2011/Accepted: 20 July 2011/Published online: 3 August 2011

(C) The Author(s) 2011. This article is published with open access at Springerlink.com

\begin{abstract}
Research in the past few decades has shown the potential benefits of using ultrasound treatment as a technique to enhance tenderness and sensory properties of meat and its sub-products. The objective of current study was to assess whether the low-frequency, low-intensity ultrasound treatment at $24 \mathrm{~h}$ postmortem affects the $\mathrm{pH}$, WarnerBratzler shear force (WBSF), colour $\left(\mathrm{CIE} \mathrm{L}{ }^{*} \mathrm{a}^{*} \mathrm{~b}^{*} \mathrm{c}^{*} \mathrm{H}^{\circ}\right.$ ), and relative proportions of myoglobin $(\mathrm{Mb})$ redox forms and total $\mathrm{Mb}$ concentration during $96 \mathrm{~h}$ of beef (musculus semimembranosus) storage. Muscles were obtained from young bulls ( $n=15$ ) of Lowland Black and White breed slaughtered at a live weight of 475 (SD 16.1) kg. Ultrasound treatment did not have a statistically significant $(p<0.05)$ effect on the $\mathrm{pH}$ of meat directly after sonication (24 h postmortem), or at 72 and $96 \mathrm{~h}$ postmortem. Sonicated meat sample (S) was characterized by higher, but not statistically significant $(p<0.05)$, $\mathrm{L} *$ coordinate values 24, 48 and $72 \mathrm{~h}$ postmortem. During the whole storage period, colour coordinates $\mathrm{a}^{*} \mathrm{~b}^{*} \mathrm{c} *$ and $\mathrm{H}^{\circ}$ were not significantly $(p<0.05)$ affected by sonication. Ultrasound treatment accelerated the total colour change $\Delta \mathrm{E}$, limited the formation of $\mathrm{MbO}_{2}$ and slowed down the formation of MetMb. Measurements carried out 48 and $72 \mathrm{~h}$ after slaughter revealed that the ultrasound treatment significantly $(p<0.05)$ reduced the WBSF. This study demonstrates the potential of low-frequency, low-intensity ultrasound treatment at $24 \mathrm{~h}$ postmortem for beef tenderization without detrimental effects on its CIE colour parameters and relative proportions of $\mathrm{Mb}$ redox forms.
\end{abstract}

J. Stadnik $(\varangle) \cdot$ Z. J. Dolatowski Department of Meat Technology and Food Quality, University of Life Sciences in Lublin, ul. Skromna 8, 20-704 Lublin, Poland e-mail: joanna.stadnik@up.lublin.pl
Keywords Sonication · Beef · Tenderness · Colour · Myoglobin

\section{Introduction}

One of the most important quality attributes affecting consumer satisfaction and positive perception of beef is its tenderness. Inconsistency in beef tenderness has been rated as one of the major problems faced by the meat industry [1]. Traditional ageing relies on endogenous proteases; however, it is time-consuming, and a considerable proportion of meat remains undesirably tough $[2,3]$. Meat tenderness can be controlled by manipulating postslaughter conditions through the use of physical methods, such as electrical stimulation [4] and tenderstretch (pelvic suspension) of the prerigor carcass [5]. Postrigor meat tenderness can also be improved by mechanical methods such as blade tenderization [6], highpressure technology [7] or Hydrodyne process [8]. The importance of tenderness in determining meat acceptability and the need for processes giving consistent and rapid improvements in tenderness mean that other processes must be evaluated.

Research in the past few decades has shown the potential benefits of using ultrasound treatment as a technique to enhance tenderness and sensory properties of meat and meat products. However, findings from the studies are inconsistent [9]. Applications of ultrasound to provoke changes in physical and chemical properties of meat have attracted the interest of research workers because it is a pure physical technique, providing an alternative to chemical or thermal means of processing [10]. Ultrasound was tested for its ability to induce membrane cell disruption that could increase meat tenderness either directly, 
through the physical weakening of muscle structure, or indirectly, by the activation of proteolysis either by release of cathepsins from lysosomes and/or of $\mathrm{Ca}^{++}$ions from intracellular stores, so that it may activate the calpains [11].

While a number of workers have investigated the use of ultrasound in meat tenderization [3, 10, 12-16], the conclusions have been mixed. Smith et al. [12] showed that low-frequency $(25.9 \mathrm{kHz})$ ultrasonic treatments of short durations ( 2 or $4 \mathrm{~min}$ ) can reduce meat toughness, but a longer treatment time $(8 \mathrm{~min})$ did not lead to the same effect. Jayasooriya et al. [10] contributed meat tenderization to high-power ultrasound $\left(24 \mathrm{kHz}, 12 \mathrm{~W} \mathrm{~cm}^{-2}\right)$ treatment for up to $4 \mathrm{~min}$. Analysis of other studies [16] suggested that low-intensity ultrasound $(20 \mathrm{kHz}$, $\left.1.55 \mathrm{~W} \mathrm{~cm}^{-2}\right)$ or high-intensity ultrasound $(20 \mathrm{kHz}$, $62 \mathrm{~W} \mathrm{~cm}^{-2}$ ) applied for short processing time (15 s) was insufficient to induce tenderization effect [14, 15].

The visual appearance of meat, particularly colour, has a major effect on consumer decision when purchasing meat or meat products [17]. From the consumers" point of view, it is very important that methods used for meat processing should not deteriorate its colour. As Pohlman et al. [3] reported that ultrasound treatment can cause changes in meat appearance due to heating by dissipation of ultrasound energy, it is important to determine whether sonication affects meat colour.

Studies on the determination of the influence of ultrasound treatment on meat colour are limited to the CIE colour parameters measurement [10] or estimation of oxymyoglobin proportion of the myoglobin pigment on the basis of reflectance differences and ratios between 610 or 630 and $580 \mathrm{~nm}[3,16]$. To our knowledge, at present, no data are available in the scientific literature dealing with the level of total myoglobin content and the proportions of related heme pigments determined by absorbance measurements. This method measures the heme pigment content of the total meat sample, in contrast to reflectance methods, which indicates the pigment content only at the meat surface.

The continuing demand for meat tenderization techniques and inconsistent results of previous studies mean further research is needed to clarify the application of ultrasound for meat tenderization. Bearing in mind the importance of meat colour in consumer acceptance, it is important to determine whether the ultrasound treatment influences the relative proportions of oxymyoglobin, myoglobin and metmyoglobin.

The objective of current study was to assess whether the low-frequency low-intensity ultrasound treatment at $24 \mathrm{~h}$ postmortem affects the $\mathrm{pH}$ of meat, its colour (CIE $\mathrm{L}^{*} \mathrm{a}^{*} \mathrm{~b}^{*} \mathrm{c}^{*} \mathrm{H}^{\circ}$ ), shear force and relative proportions of $\mathrm{Mb}$ redox forms and total $\mathrm{Mb}$ concentration during $96 \mathrm{~h}$ of beef storage.

\section{Materials and methods}

Animal management

Fifteen entire young bulls of Lowland Black and White breed (age 24-30 months) at a live weight of 475 (SD 16.1) $\mathrm{kg}$ were slaughtered following standard procedure at an EU-approved abattoir near Lublin. Animals were housed in separate pens using straw as bedding. All animal had the same feeding regime. They were offered a mixed diet consisting of ad libitum grass silage, concentrate and hay. Transportation time from the farm to the slaughter house did not exceed $2 \mathrm{~h}$. Lairage times ranged from 2 to $12 \mathrm{~h}$, with mean lairage time of $6.7 \mathrm{~h}$. After lairage, bulls were stunned by captive bolt method and dressed using standard commercial procedures.

Experimental design

The muscles (m. semimembranosus), free from slaughter/ dressing defects (e.g., major fat tears, large bruises), were excised at $24 \mathrm{~h}$ postmortem from left half-carcasses chilled at $2{ }^{\circ} \mathrm{C}$. The middle part of this muscle, free of external fat and connective tissue, was divided into eight blocks $(70 \mathrm{~mm} \times 70 \mathrm{~mm} \times 80 \mathrm{~mm}$, length, width and height, respectively) of about $400 \mathrm{~g}$. Four of the parts were regarded as control samples $(\mathrm{C})$ and stored in polyethylene bags at $4{ }^{\circ} \mathrm{C}$. The other four were subjected to ultrasound treatment with frequency of $45 \mathrm{kHz}$ (sample S). According to the method reported by Lyng et al. [18], the experimental design was a randomized block type with possible differences in results among the differences of the muscle being averaged out over treatments. In order to carry out ultrasound treatment, samples packed in polyethylene bags were placed into an ultrasound bath (Polsonic, Warsaw, Poland) filled with cold water $\left(4^{\circ} \mathrm{C}\right)$ and then sonicated. The low-intensity ultrasonic field $\left(2 \mathrm{~W} \mathrm{~cm}^{-2}\right)$ was applied perpendicularly to muscle fibres for $120 \mathrm{~s}$. Temperature of the water bath was monitored during treatment, and ice was added to maintain it at the level of $4 \pm 1{ }^{\circ} \mathrm{C}$. Meat samples were then repacked and stored at $4{ }^{\circ} \mathrm{C}$ until assessed. The samples were examined at the following times postmortem: 24, 48, 72 and $96 \mathrm{~h}$ (i.e. 0, 24, 48 and $72 \mathrm{~h}$ after ultrasound treatment). In meat processing, it is common practice to cut muscles from carcasses as early as possible. Polish Standard [19] requires beef primal cuts to be aged no longer than $60 \mathrm{~h}$ after excision.

$\mathrm{pH}$

The $\mathrm{pH}$ was measured with an insertion glass electrode (OSH 12-00 Metron, Poland) fitted to a digital pH-meter (CPC-501 Elmetron, Poland). The electrode was driven into meat sample at the depth of about $5 \mathrm{~cm}$. The probe has 
been calibrated at the temperature of $4{ }^{\circ} \mathrm{C}$. The $\mathrm{pH}$-meter was recalibrated for each sample. Measurements were carried out in triplicate at random points of the sample.

Instrumental colour

Samples were evaluated for instrumental colour at their assigned time postmortem $(24,48,72$ or $96 \mathrm{~h}$ ) by using an X-Rite Color ${ }^{\circledR}$ Premiere 8,200 spectrophotometer (X-Rite Incorporated, Michigan, USA) following the recommendations of American Meat Science Association [20]. The instrumental conditions were an 8.43 -cm-diameter area aperture, illuminant D65 and a $10^{\circ}$ standard observer.

Samples for colour measurements were $5 \mathrm{~cm}$ thick and excided at the depth of $20 \mathrm{~mm}$. Before colour determination, meat samples wrapped in an oxygen permeable polyethylene film were allowed to bloom for $30 \mathrm{~min}$ at $4 \pm 1{ }^{\circ} \mathrm{C}$. Every time before use, the instrument was standardized against a white ceramic calibration tile with a specification of $\mathrm{L}^{*}=95.87, \mathrm{a}^{*}=-0.49, \mathrm{~b}^{*}=2.39$ that was wrapped in the same polyethylene film used for the meat samples, and a light trap. Meat colour measurements were made in triplicate at randomly selected locations with care to avoid areas of clearly visible connective and adipose tissues. Colour measurement followed the Commission Internationale de $1^{‘}$ Eclairage (CIE) colour convention [21], with outputs of $\mathrm{L}^{*}$ (lightness/darkness), $\mathrm{a}^{*}$ (red/green), $\mathrm{b}^{*}$ (yellow/blue), $\mathrm{c}^{*}$ (chroma) as $\mathrm{c}^{*}=\left(\mathrm{a}^{* 2}+\mathrm{b}^{* 2}\right)^{1 / 2}$ and $\mathrm{H}^{\circ}$ (hue angle) as $\mathrm{H}^{\mathrm{o}}=\arctan \left(\mathrm{b}^{*} / \mathrm{a}^{*}\right)$.

In addition, the total colour change $(\Delta \mathrm{E})$ was calculated according to CIE equation:

$\left.\Delta \mathrm{E}=\left[\left(\Delta \mathrm{L}_{n-0}^{*}\right)^{2}+\left(\Delta \mathrm{a}_{n-0}^{*}\right)^{2}+\left(\Delta \mathrm{b}_{n-0}^{*}\right)^{2}\right)\right]^{1 / 2}$

where $\Delta \mathrm{L}_{n-0}^{*}, \Delta \mathrm{a}_{n-0}^{*}$ and $\Delta \mathrm{b}_{n-0}^{*}$ are the differences between $\mathrm{L}^{*}, \mathrm{a}^{*}$ and $\mathrm{b}^{*}$ measured at an hour $\mathrm{n}$ postmortem and their values at $24 \mathrm{~h}$ postmortem.

Relative proportions of $\mathrm{Mb}$ redox forms and total $\mathrm{Mb}$ concentration in meat extracts

The total myoglobin content $(\mathrm{Mb})$ and the proportion of myoglobin $(\mathrm{Mb})$, oxymyoglobin $\left(\mathrm{MbO}_{2}\right)$ and metmyoglobin (MetMb) in meat samples were determined according to Krzywicki [22] using a $40 \mathrm{mM}$ phosphate extraction buffer (pH 6.8). By means of reflectance values read at 572 , 565,545 , and $525 \mathrm{~nm}$ in a UV-VIS spectrophotometer (Nicolet Evolution 300 BB, Thermo Fisher Scientific, Waltham, USA), the total myoglobin content and the proportions of myoglobin, oxymyoglobin and metmyoglobin were calculated. For the total myoglobin content, the values were converted to $\mathrm{mg} \mathrm{g}^{-1}$ meat based on the dilution and the molecular weight $(17,500 \mathrm{D})$ of myoglobin.
Shear force

After the respective ageing time, meat samples were prepared for shear force analysis. Blocks of $80 \pm 2 \mathrm{~g}$ were cooked individually in plastic bags immersed in a water bath (PolyScience, Niles, IL, United States) at $80{ }^{\circ} \mathrm{C}$ for $1 \mathrm{~h}$. The cooked meat was cooled in cold running water for $30 \mathrm{~min}$. Samples were then dried with paper towel to remove excess moisture and 3 cylindrical cores (Ø $1.25 \mathrm{~cm}$ ), minimum $30 \mathrm{~mm}$ long, parallel to the longitudinal orientation of the muscle fibres were taken and sheared by a V-shaped Warner-Bratzler blade (thickness: $0.9 \mathrm{~mm}$ ) with a triangular aperture of $60^{\circ}$ at a crosshead speed of $100 \mathrm{~mm} \mathrm{~min}^{-1}$. Peak force (N) to cut across each piece was determined with a texture analyzer TA-XT plus (Stable Micro Systems Ltd. Surrey, UK). Data were collected with Texture Expert Exceed software (Stable Micro Systems).

\section{Statistical analysis}

Measurements were made in triplicate, and the obtained results were statistically analysed using the Statgraphics v. 5 (Manugistics Inc. Rockville). A mean and standard error was calculated for each test. Two-way analysis of variance (ANOVA) was carried out. Significance of differences between samples was determined (at the significance level $p<0.05)$ using Tukey's test.

\section{Results}

$\mathrm{pH}$

Obtained results (Fig. 1) pointed out that ultrasound treatment did not have a statistically significant $(p<0.05)$ effect on the $\mathrm{pH}$ of the meat directly after sonication $(24 \mathrm{~h}$ postmortem), or at 72 and $96 \mathrm{~h}$ postmortem. Results of $\mathrm{pH}$ measurements reached $48 \mathrm{~h}$ after slaughter for sonicated sample were significantly higher than those obtained for $\mathrm{C}$ sample. Since that time, $\mathrm{pH}$ of both samples tended to increase with increasing ageing time.

Instrumental colour

Table 1 show results of colour coordinates $\mathrm{L}^{*} \mathrm{a}^{*} \mathrm{~b}^{*} \mathrm{c}^{*} \mathrm{H}^{\circ}$ measurements carried out 24, 48, 72 and $96 \mathrm{~h}$ after slaughter.

Sonicated meat sample (S) was characterized by higher, but not statistically significant $(p<0.05), \mathrm{L}^{*}$ coordinate values 24,48 and $72 \mathrm{~h}$ postmortem (Table 1). The passage of ageing time did not have an influence on the changes of the $\mathrm{L}^{*}$ coordinate for both samples. The most noticeable 


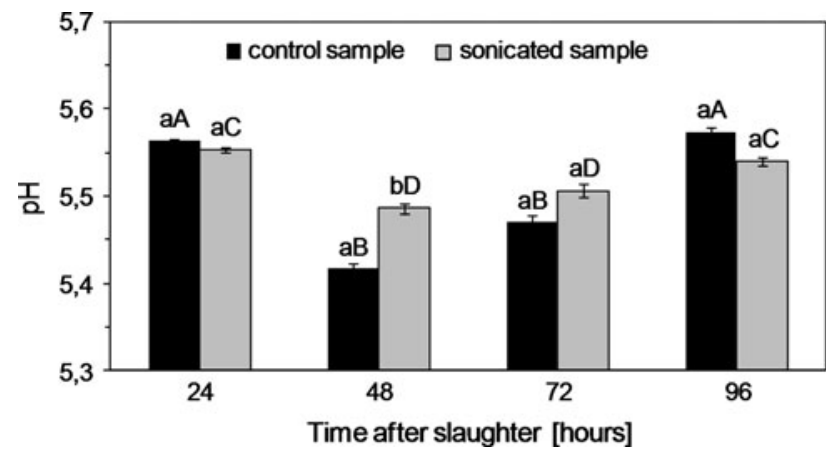

Fig. 1 Influence of sonication and ageing time on meat $\mathrm{pH}$. Within the same time group, means followed by the common small letter do not differ significantly $(p<0.05)$. Means within a given treatment followed by the common capital letter do not differ significantly $(p<0.05)$. Error bars represent \pm standard error

decrease in the $\mathrm{L}^{*}$-value of sample $\mathrm{S}$ was seen between hour 72 and 96.

Application of ultrasound did not significantly affect the $a^{*}$ colour parameter during the whole storage period of examined meat samples (Table 1). The a colour value of both samples was increasing slightly while ageing. Significantly higher values of coordinate a ${ }^{*}$ were noted $96 \mathrm{~h}$ after slaughter in comparison with results reached $24 \mathrm{~h}$ postmortem. No significant increase in $\mathrm{a}^{*}$ value was observed between 48 and $72 \mathrm{~h}$.

No statistically significant effect of ultrasound treatment on the $b^{*}$ colour parameter was observed (Table 1). The most noticeable increase in the blue-yellow chromatically $\left(b^{*}\right)$ values was seen between hour 24 and 48 . There were no other significant differences between samples during further ageing period.

As far as results of colour coordinate $\mathrm{c}^{*}$ measurements are concerned (Table 1), no significant differences between results obtained for both samples were noted.

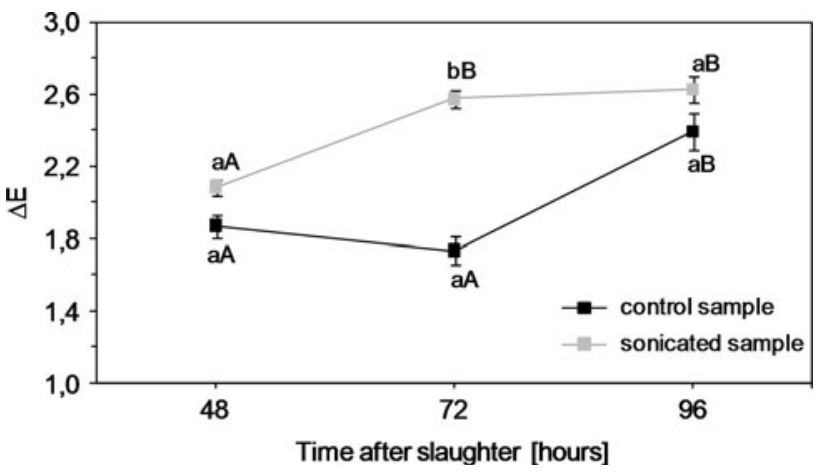

Fig. 2 Influence of sonication and ageing time on value E. Within the same time group, means followed by the common small letter do not differ significantly $(p<0.05)$. Means within a given treatment followed by the common capital letter do not differ significantly $(p<0.05)$. Error bars represent \pm standard error

During the whole storage period, colour coordinate $\mathrm{H}^{\circ}$ was not significantly affected by ultrasound treatment (Table 1). The most noticeable increase for sample $\mathrm{C}$ was observed $48 \mathrm{~h}$ after slaughter as compared to results obtained $24 \mathrm{~h}$ earlier. Similar situation took place $72 \mathrm{~h}$ postmortem for sample $\mathrm{S}$. The observed changes were not statistically significant.

Analysis of total colour change showed an influence of ageing time and ultrasound treatment on meat colour stability (Fig. 2). $\Delta \mathrm{E}$ values of the control sample varied from 1.87 to 2.62 , whereas $\Delta \mathrm{E}$ values of the $\mathrm{S}$ sample varied from 2.18 to 2.78. Colour of sonicated meat sample (S) was less stable as compared to the control sample (C). Ultrasound treatment accelerated the total colour change $\Delta \mathrm{E}$. The most noticeable differences between samples were observed $72 \mathrm{~h}$ postmortem. Ageing time affected the total colour change of both samples. For the sonicated sample, statistically significant increase was noted at $72 \mathrm{~h}$ postmortem, for the control sample it took place $24 \mathrm{~h}$ later.

Table 1 Influence of sonication and ageing time on the colour coordinates $\mathrm{L}^{*} \mathrm{a}^{*} \mathrm{~b}^{*} \mathrm{c}^{*} \mathrm{H}^{\circ}$

\begin{tabular}{|c|c|c|c|c|c|}
\hline \multirow[t]{2}{*}{ Sample } & \multirow{2}{*}{$\begin{array}{l}\text { Colour } \\
\text { coordinate }\end{array}$} & \multicolumn{4}{|c|}{ Time after slaughter (h) } \\
\hline & & 24 & 48 & 72 & 96 \\
\hline $\mathrm{C}$ & $\mathrm{L}^{*}$ & $39.83 \pm 0.71^{\mathrm{aA}}$ & $40.43 \pm 1.04^{\mathrm{aA}}$ & $40.16 \pm 0.85^{\mathrm{aA}}$ & $40.35 \pm 0.25^{\mathrm{aA}}$ \\
\hline $\mathrm{S}$ & & $40.46 \pm 1.40^{\mathrm{aA}}$ & $40.53 \pm 0.82^{\mathrm{aA}}$ & $41.72 \pm 0.93^{\mathrm{aA}}$ & $39.22 \pm 1.31^{\mathrm{aA}}$ \\
\hline $\mathrm{C}$ & $a^{*}$ & $10.71 \pm 0.59^{\mathrm{aA}}$ & $11.38 \pm 0.68^{\mathrm{aAB}}$ & $12.04 \pm 0.52^{\mathrm{aAB}}$ & $12.68 \pm 0.75^{\mathrm{aB}}$ \\
\hline $\mathrm{S}$ & & $10.39 \pm 0.52^{\mathrm{aA}}$ & $11.91 \pm 0.50^{\mathrm{aAB}}$ & $11.84 \pm 0.20^{\mathrm{aAB}}$ & $12.23 \pm 0.43^{\mathrm{aB}}$ \\
\hline $\mathrm{C}$ & $b^{*}$ & $7.93 \pm 0.49^{\mathrm{aC}}$ & $9.57 \pm 0.51^{\mathrm{aB}}$ & $8.99 \pm 0.32^{\mathrm{aAB}}$ & $9.18 \pm 0.39^{\mathrm{aAB}}$ \\
\hline S & & $7.78 \pm 0.91^{\mathrm{aA}}$ & $9.20 \pm 0.47^{\mathrm{aAB}}$ & $9.61 \pm 0.52^{\mathrm{aB}}$ & $9.00 \pm 0.73^{\mathrm{aAB}}$ \\
\hline $\mathrm{C}$ & $c^{*}$ & $13.34 \pm 0.72^{\mathrm{aA}}$ & $15.17 \pm 0.76^{\mathrm{aA}}$ & $15.03 \pm 0.57^{\mathrm{aA}}$ & $15.67 \pm 0.83^{\mathrm{aA}}$ \\
\hline S & & $13.02 \pm 0.97^{\mathrm{aA}}$ & $15.07 \pm 0.66^{\mathrm{aA}}$ & $15.28 \pm 0.34^{\mathrm{aA}}$ & $15.22 \pm 0.70^{\mathrm{aA}}$ \\
\hline $\mathrm{C}$ & $\mathrm{H}^{\circ}$ & $36.53 \pm 1.21^{\mathrm{aA}}$ & $39.23 \pm 1.43^{\mathrm{aA}}$ & $36.82 \pm 0.81^{\mathrm{aA}}$ & $36.04 \pm 0.51^{\mathrm{aA}}$ \\
\hline S & & $36.22 \pm 1.98^{\mathrm{aA}}$ & $37.43 \pm 1.08^{\mathrm{aA}}$ & $38.92 \pm 1.66^{\mathrm{aA}}$ & $36.16 \pm 1.87^{\mathrm{aA}}$ \\
\hline
\end{tabular}

Means in a column followed by the common small letter do not differ significantly at $p<0.05$. Means in a row followed by the common capital letter do not differ significantly at $p<0.05$. Error bars represent \pm standard error 
Table 2 Relative proportions of Mb redox forms and total Mb concentration in meat samples

\begin{tabular}{llcccc}
\hline Sample & Parameter & \multicolumn{3}{l}{ Time after slaughter $(\mathrm{h})$} & \\
\cline { 3 - 6 } & & 24 & 48 & 72 & 96 \\
\hline $\mathrm{C}$ & Total myoglobin content $\left(\mathrm{mg}^{-1)}\right.$ & $9.961 \pm 0.099^{\mathrm{aA}}$ & $9.212 \pm 0.049^{\mathrm{aA}}$ & $9.773 \pm 0.067^{\mathrm{aA}}$ & $9.208 \pm 0.088^{\mathrm{aA}}$ \\
$\mathrm{S}$ & & $9.773 \pm 0.074^{\mathrm{aAB}}$ & $10.149 \pm 0.083^{\mathrm{bB}}$ & $9.585 \pm 0.071^{\mathrm{aA}}$ & $9.322 \pm 0.124^{\mathrm{aA}}$ \\
$\mathrm{C}$ & $\mathrm{Mb}(\%)$ & $16.598 \pm 2.617^{\mathrm{aB}}$ & $14.766 \pm 2.010^{\mathrm{aA}}$ & $15.876 \pm 2.363^{\mathrm{aAB}}$ & $14.273 \pm 2.002^{\mathrm{aA}}$ \\
$\mathrm{S}$ & & $16.141 \pm 2.243^{\mathrm{aA}}$ & $22.944 \pm 3.528^{\mathrm{bB}}$ & $17.945 \pm 2.023^{\mathrm{aA}}$ & $13.922 \pm 1.994^{\mathrm{aC}}$ \\
$\mathrm{C}$ & $\mathrm{MbO}_{2}(\%)$ & $67.305 \pm 4.309^{\mathrm{aA}}$ & $69.429 \pm 3.108^{\mathrm{aA}}$ & $65.790 \pm 2.164^{\mathrm{aAB}}$ & $63.296 \pm 2.345^{\mathrm{aB}}$ \\
$\mathrm{S}$ & & $67.725 \pm 3.551^{\mathrm{aA}}$ & $64.953 \pm 3.062^{\mathrm{aAB}}$ & $63.441 \pm 3.329^{\mathrm{aB}}$ & $65.276 \pm 2.403^{\mathrm{aAB}}$ \\
$\mathrm{C}$ & $\mathrm{MetMb}^{\mathrm{aA}} \%$ & $7.840 \pm 1.444^{\mathrm{aA}}$ & $8.975 \pm 0.834^{\mathrm{aA}}$ & $13.211 \pm 0.814^{\mathrm{aB}}$ & $16.145 \pm 2.089^{\mathrm{aB}}$ \\
$\mathrm{S}$ & & $8.674 \pm 0.796^{\mathrm{aA}}$ & $9.737 \pm 0.614^{\mathrm{aA}}$ & $10.603 \pm 0.863^{\mathrm{bA}}$ & $14.269 \pm 0.977^{\mathrm{aB}}$ \\
\hline
\end{tabular}

Means in a column followed by the common small letter do not differ significantly at $p<0.05$. Means in a row followed by the common capital letter do not differ significantly at $p<0.05$. Error bars represent \pm standard error

Content of myoglobin and of related pigments

The total myoglobin content of the meat samples kept for $96 \mathrm{~h}$ at $4{ }^{\circ} \mathrm{C}$ ranged from 9.208 to $10.149 \mathrm{mg} \mathrm{g}^{-1}$ (Table 2). Statistical analysis revealed significant difference in the total myoglobin concentration between samples at $48 \mathrm{~h}$ postmortem. During further ageing period as well as at the start of the experiment, the concentration of myoglobin was similar in both samples.

The proportion of myoglobin (\%) in sonicated meat sample was similar to that in the control sample. Statistically significant differences between samples were observed $48 \mathrm{~h}$ after slaughter.

There were no significant differences in the oxymyoglobin $\left(\mathrm{MbO}_{2}\right)$ concentration between meat samples during ageing.

Significantly lower concentration of MetMb in sonicated meat sample as compared to the control sample was observed $72 \mathrm{~h}$ postmortem. Results of determination of haem pigments concentration show that the passage of time after slaughter was coupled with an increase in MetMb concentration. For the control sample, the statistically significant increase in MetMb concentration was noted at $72 \mathrm{~h}$ postmortem. With regard to the sonicated sample, similar situation took place $24 \mathrm{~h}$ later.

It suggests that sonication limited the formation of $\mathrm{MbO}_{2}$ and slowed down the formation of MetMb in sonicated beef.

\section{Shear force}

Results of measurements carried out 48 and $72 \mathrm{~h}$ after slaughter revealed that the ultrasound treatment significantly reduced the shear force (Fig. 3). Peak force values declined with longer ageing time. For the sonicated meat sample, there was a significant decrease in WBSF between 24 and $48 \mathrm{~h}$, with no significant change during further

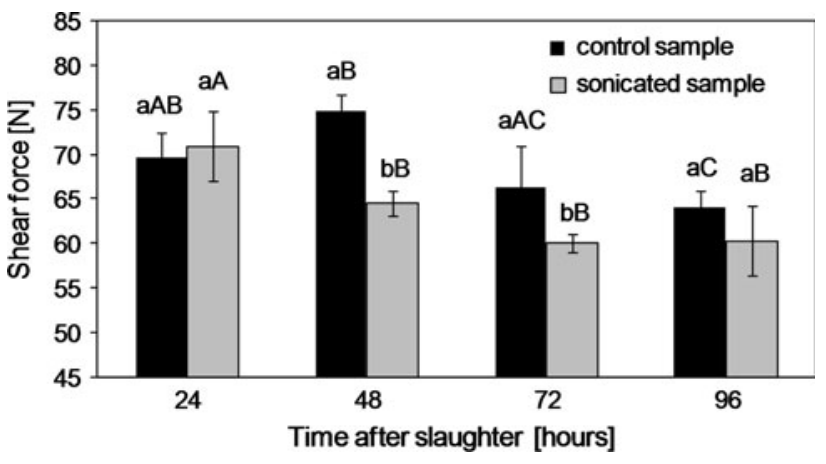

Fig. 3 Influence of sonication and ageing time on shear force. Within the same time group, means followed by the common small letter do not differ significantly $(p<0.05)$. Means within a given treatment followed by the common capital letter do not differ significantly $(p<0.05)$. Error bars represent \pm standard error

storage period. As far as the control sample is concerned, a significant decrease in the shear force was observed at $72 \mathrm{~h}$.

\section{Discussion}

In this study, the influence of meat sonication on WarnerBratzler shear force, colour and myoglobin of beef was examined. Ultrasound treatment gave lower peak force values at 48 and $72 \mathrm{~h}$ postmortem. The decline in shear force values with longer storage time was expected and agrees with several other studies [23-25]. Results of previous research [26] under exactly identical experimental conditions have demonstrated that due to ultrasound treatment at rigor mortis acceleration of proteolysisinduced improvement in tenderness occurred, followed by a fragmentation of proteins structures of cell. It was confirmed by results of water holding capacity measurements and microstructure changes during meat ageing. On the 
basis of water compartmentalization assessed by means of NMR technique as well as by microstructure analysis, the differences in water mobility within protein structure of myofibrils during ageing were found. Decrease in WBSF observed for sonicated samples in present study may result from the same mechanisms, i.e. acceleration of postmortem changes and altered water compartmentalization within muscle tissue.

Ultrasound treatment of meat has produced inconsistent effects on meat tenderness, with some ultrasound treatments producing no effect on tenderness, while others decreased or increased tenderness [9]. Acoustic parameters (frequency, intensity, duration of treatment, temperature) determine the extent of the desired result achieved from sonication. Some studies show increased tenderness with low-frequency ultrasound $(22-40 \mathrm{kHz})$ treatment [27, 28]. Zayas and Gorbatow [29] also reported the improvement in the tenderness of meat immersed in brine, sonifying at frequency of $22 \mathrm{kHz}$ and $1.5-3 \mathrm{~W} \mathrm{~cm}^{-2}$. Experiments carried out on Semimembranosus muscle showed that ultrasound treatment (frequency $25 \mathrm{kHz}$; intensity $2 \mathrm{~W} \mathrm{~cm}^{-2}$ ) during rigor mortis period (up to $24 \mathrm{~h}$ postmortem) resulted in improved tenderness of meat during its ageing. The changes in sarcomere structure as well as higher WHC were observed for sonicated samples [30]. Alterations in muscle structure, particularly the loss of the typical myofibrillar structure, were observed for sonicated horse Semimembranosus muscle pumped with brine [28]. Ultrasound treatment caused fragmentation of myofibrils and disintegration of other cellular components [27]. Ultrasound-assisted process of meat tumbling caused the significant improvement in the yield, tenderness and juiciness of the end product [31]. Sonication resulted in decreased drip loss and shear force of PSE meat [32].

Other studies showed that ultrasound did not tenderize meat samples. This may be due to the use of relatively lowintensity ultrasound baths $\left(0.29-1.55 \mathrm{~W} \mathrm{~cm}^{-2}\right)[16,18]$, or high-intensity ultrasound $\left(62 \mathrm{~W} \mathrm{~cm}^{-2}\right)$ applied to individual regions of the meat sample for short treatment time (15 s) [14, 15], which may have been insufficient to produce a tenderizing effect. Smith et al. [12] exposed semitendinosus muscle to ultrasound source at a frequency of $25.9 \mathrm{kHz}$ in a water bath (filled with degassed saline). Samples that were treated for 2 or 4 min had significantly lower shear force values than the untreated controls. However, at longer treatment times ( 8 or $16 \mathrm{~min}$ ), the shear force increased. In a study of the effect of high-frequency ultrasound on meat texture, pre- and postrigor meat was treated with high-frequency, high-intensity ultrasound (2.6 $\mathrm{MHz}, 10 \mathrm{~W} \mathrm{~cm}^{-2}$ ) [13]. Pre- and post-rigor ultrasound treatments had small effects on raw meat texture, with ultrasound treated meat having a slightly softer raw meat texture after 3-6 days ageing. The difference between control and ultrasound treated sample texture had disappeared after 14 days ageing. However, the results of different studies may not be comparable because of differences in the type of muscles used, the animal age, the ultrasonic equipment and efficiency, intensities, frequencies and the durations of ultrasound treatments.

Results of present research regarding CIE L ${ }^{*}{ }^{*} b^{*}$ colour parameters are not consistent with earlier studies [3], who reported that sonicated bovine Pectoralis muscle became lighter (higher $\mathrm{L}^{*}$ ), less red (lower a*), more yellow (higher $\mathrm{b}^{*}$ ), more orange (higher hue angle), and less bright (lower saturation) as compared to controls. This discrepancy may be due to the greater treatment time (up to $600 \mathrm{~s}$ ) and power level $\left(22 \mathrm{~W} \mathrm{~cm}^{-2}\right.$ at $\left.20 \mathrm{kHz}\right)$ used by Pohlman et al. [3] as compared to the present study $\left(120 \mathrm{~s} ; 2 \mathrm{~W} \mathrm{~cm}^{-2}\right.$ at $45 \mathrm{kHz}$ ), though Pohlman et al. [3] did use a smaller sample $(80 \times 80 \times 25 \mathrm{~mm})$ compared to the present study $(70 \times 70 \times 80 \mathrm{~mm})$.

\section{Conclusions}

Ultrasound treatment gave lower peak force values at 48 and $72 \mathrm{~h}$ postmortem. Obtained results pointed out that sonication did not influence the CIE colour parameters of meat during ageing, but this treatment accelerated the total colour change $\Delta \mathrm{E}$. Colour of sonicated sample was slightly less stable as compared to the control sample. During the experiment, relative proportions of $\mathrm{Mb}$ redox forms and total $\mathrm{Mb}$ concentration were similar for both meat samples. This study demonstrates the potential of ultrasound application for meat tenderization without detrimental effects on its colour.

Open Access This article is distributed under the terms of the Creative Commons Attribution Noncommercial License which permits any noncommercial use, distribution, and reproduction in any medium, provided the original author(s) and source are credited.

\section{References}

1. Koohmaraie M (1996) Biochemical factors regulating the toughening and tenderization processes of meat. Meat Sci 43(Suppl 1):193-201

2. Koohmaraie M (1994) Muscle proteinases and meat aging. Meat Sci 36:93-104

3. Pohlman FW, Dikeman ME, Kropf DH (1997) Effects of high intensity ultrasound treatment, storage time and cooking method on shear, sensory, instrumental color and cooking properties of packaged and unpackaged beef pectoralis muscle. Meat Sci 46:89-100

4. Hwang IH, Thompson JM (2001) The effect of time and type of electrical stimulation on the calpain system and meat tenderness in beef Longissimus dorsi muscle. Meat Sci 58:135-144

5. Fisher AV, Pouros A, Wood JD, Young-Boong K, Sheard PR (2000) Effect of pelvic suspension on three major leg muscles in 
the pig carcass and implications for ham manufacture. Meat Sci $56: 127-132$

6. Hayward LH, Hunt MC, Kastner LC, Kropf DJ (1980) Blade tenderization effects on beef Longissimus sensory and instron textural measurements. J Food Sci 45:925-935

7. Cheftel JC, Culioli J (1997) Effects of high pressure on meat: a review. Meat Sci 46:211-236

8. Solomon MB, Long JB, Eastridge JS (1997) The hydrodyne: a new process to improve beef tenderness. J Anim Sci $75: 1534-1537$

9. Jayasooriya SD, Bhandari BR, Torley P, D‘Arcy BR (2004) Effect of high power ultrasound waves on properties of meat: a review. Int J Food Prop 7:301-319

10. Jayasooriya SD, Torley PJ, D‘Arcy BR, Bhandari BR (2007) Effect of high power ultrasound and ageing on the physical properties of bovine semitendinosus and longissimus muscles. Meat Sci 75:628-639

11. Dransfield E (1993) Modelling post-mortem tenderization-IV: role of calpains and calpastatin in conditioning. Meat Sci 34:217-234

12. Smith NB, Cannon JE, Novakofski JE, McKeith FK, O'Brien WD (1991) Tenderization of semitendinosus muscle using high intensity ultrasound. In: Proceedings of the IEEE ultrasonics symposium, 8-11 December 1991, Orlando, FL, USA, pp 1371-1374

13. Got F, Culioli J, Berge P, Vignon X, Astruc T, Quideau JM, Lethiecq M (1999) Effects of high-intensity high frequency ultrasound on ageing rate, ultrastructure and some physicochemical properties of beef. Meat Sci 51:35-42

14. Lyng JG, Allen P, McKenna B (1998) The effects of pre- and post-rigor high-intensity ultrasound treatment on aspects of lamb tenderness. LWT-Food Sci Technol 31:334-338

15. Lyng JG, Allen P, McKenna BM (1998) The effect on aspects of beef tenderness of pre- and post-rigor exposure to a high intensity ultrasound probe. J Sci Food Agric 78:308-314

16. Pohlman FW, Dikeman ME, Zayas JF (1997) The effect of lowintensity ultrasound treatment on shear properties, color stability and shelf life of vacuum packaged beef semitendinosus and biceps femoris muscles. Meat Sci 45:329-337

17. Bekhit AED, Faustman C (2005) Metmyoglobin reducing activity. Meat Sci 71:407-439
18. Lyng JG, Allen P, McKenna BM (1997) The influence of high intensity ultrasound baths on aspects of beef tenderness. J Muscle Foods 8:237-249

19. Polish Standard PN-88/A-82003. Beef. Primal cuts (in Polish)

20. American Meat Science Association (1991) Guidelines for meat color evaluation. Chicago, IL

21. Commission Internationale de 1'Eclairage (CIE) (1978) Supplement no. 2 to CIE publication no. 15 colorimetry. Bureau Central de la CIE, Paris

22. Krzywicki K (1982) The determination of haem pigments in meat. Meat Sci 7:29-36

23. Crouse JD, Koohmaraie M (1990) Effect of freezing of beef on subsequent postmortem ageing and shear force. J Food Sci 55:573-574

24. Monsón F, Sañundo C, Sierra I (2004) Influence of cattle breed and ageing time on textural meat quality. Meat Sci 68:595-602

25. Sherbeck JA, Tatum JD, Field TG, Morgan JB, Smith GC (1995) Feedlot performance, carcass traits, and palatability traits of Hereford and Hereford $\mathrm{x}$ Brahman steers. J Anim Sci 73:3613-3620

26. Stadnik J, Dolatowski ZJ, Baranowska HM (2008) Effect of ultrasound treatment on water holding properties and microstructure of beef (m. semimembranosus) during ageing. LWTFood Sci Technol 41:2151-2158

27. Dickens JA, Lyon CE, Wilson RL (1991) Effect of ultrasonic radiation on some physical characteristics of broiler breast muscle and cooked meat. Poult Sci 70:389-396

28. Dolatowski ZJ (1988) Ultrasonics 2 Influence of ultrasonics on the ultrastructure of muscle tissue during curing. Fleischwirtschaft 68:1301-1303

29. Zayas JF, Gorbatow WM (1978) Use of ultrasonics in meat technology. Fleischwirtschaft 6:1009-1012

30. Dolatowski ZJ, Twarda J (2004) Einfluss von Ultraschall auf das Wasserbindungsvermögen von Rindfleisch. Fleischwirtschaft 12:95-99

31. Dolatowski ZJ, Stasiak DM (1995) Tumbling machine with ultrasound. In: Proceedings 9th congress of food science and technology, 30 July-8 August 1995, Budapest, Hungary, pp 153

32. Twarda J, Dolatowski ZJ (2006) The effect of sonication on the colour and WHC of normal and PSE pork. Anim Sci 1(Suppl): 184-185 